\title{
Penggunaan Media Sosial Instagram Secara Berlebihan Dikalangan Anak Remaja
}

\author{
Muhammad Aldi Wiranata ${ }^{1}$, Opah², Moch Fajar Megantara ${ }^{3}$, Shafira Rayna Resantari ${ }^{4}$. \\ Jurusan IImu Komunikasi, Fakultas IImu komunikasi, Universitas Islam Nusantara
}

\begin{tabular}{|c|c|}
\hline ARTICLE INFO & ABSTRACT \\
\hline Article history: & \multirow{4}{*}{$\begin{array}{l}\text { It is undeniable that social media has a great influence on a person's } \\
\text { life, including teenegers. From the time of its development, at schoo } \\
\text { and outside, adolescenets try to find their identity by hanging out with } \\
\text { their peers. This study aims to determine the influence of social media. } \\
\text { Explain what the effect of social media are for adolescents in their } \\
\text { development, then to find out what are the effect on adolescen } \\
\text { behavior caused by social media, especially in the use of instagram. In } \\
\text { this study, researchers used qualitative research methods because } \\
\text { they wanted to explore facts, symphtoms and events pf the influence or } \\
\text { social media on adolescent behavior in the flied as it is in the form or } \\
\text { more complex data details about phenomena that are difficult to } \\
\text { express by quantitative methods. The result of the quantitative research } \\
\text { needed by researchers are in the form of in-depth in information abou } \\
\text { the influence of social media on adolescents themselves. }\end{array}$} \\
\hline $\begin{array}{r}\text { Received Jan 12, } 2022 \\
\text { Revised Feb 22, } 2022 \\
\text { Accepted Maret 01, } 2022\end{array}$ & \\
\hline Keywords: & \\
\hline \multirow[t]{3}{*}{$\begin{array}{l}\text { Media Sosial; } \\
\text { Anak Remaja; } \\
\text { Instagram. }\end{array}$} & \\
\hline & ABSTRAK \\
\hline & $\begin{array}{l}\text { Tidak dapat dipungkiri bahwa media sosial mempunyai pengaruh yang } \\
\text { besar dalam kehidupan seseorang termasuk remaja.Dari masa } \\
\text { perkembangannya, disekolah maupun diluar remaja berusaha mencari } \\
\text { identitasnya dengan bergaul bersama teman sebayanya. Penelitian ini } \\
\text { bertujuan untuk mengetahui pengaruh media sosial Menjelaskan } \\
\text { mengenai apa saja pengaruh media sosial bagi remaja dimasa } \\
\text { perkembangannya kemudian untuk mengetahui apa saja pengaruh } \\
\text { terhadap perilaku remaja yang disebabkan oleh media sosial saat ini } \\
\text { terlebih dalam penggunaan instagram. Dalam penelitian ini, peneliti } \\
\text { menggunakan metode penelitian kualitatif karena ingin mendalami } \\
\text { suatu fakta, gejala dan peristiwa pengaruh media sosial terhadap } \\
\text { perilaku remaja di lapangan sebagaimana adanya dalam konteks } \\
\text { ruang dan waktu serta situasi lingkungan remaja secara alami.Peneliti } \\
\text { menginginkan hasil penelitian berupa rincian data yang lebih kompleks } \\
\text { tentang fenomena yang sulit diungkapkan oleh metode kuantitatif. Hasil } \\
\text { dari penelitian kualitatif yang dibutuhkan peneliti adalah berupa } \\
\text { informasi yang mendalam mengenai pengaruh media sosial bagi } \\
\text { remaja itu sendiri. }\end{array}$ \\
\hline
\end{tabular}

This is an open access article under the CC BY-NC license.

\section{Corresponding Author:}

\section{Muhammad Aldi Wiranata}

Jurusan IImu Komunikasi, Fakultas Ilmu komunikasi, Universitas Islam Nusantara, Jawa Barat, Indonesia Jl. Soekarno-Hatta No.530, Kota Bandung, Jawa Barat 40286 Email: aldiwiranata842@gmail.com

\section{PENDAHULUAN}

Era globalisasi ini merupakanera digital, hampir semua orang mahir menggunakan gadget dan internet untuk lebih memudahkan kesehariannya, apalagi perkembangan teknologi khususnya teknologi informasi telah berkembang sangat pesat.Hal itu dibuktikan dengan adanya kemudahan 
mengakses internet untuk terhubung dengan banyak orang dari berbagai belahan dunia tanpa harus bertatap muka,dan bisa membagikan informasi kegiatan sehari-hari hanya menggunakan media sosial.Semakin berkembangnya teknologi informasi mengakibatkan penyebaran informasi menjadi semakin berkembang,salah satunya dengan muncul media baru.Sebagian besar aktivitas kehidupan masyarakat tidak dapat dipisahkan dengan intenet.Seringkali internet digunakan sebagai sarana kebutuhan untuk penggunanya seperti mendapatkan informasi,berkomunikasi dan hal lainya.

Saat ini Media sosial merupakan salah satu media yang menggunakan internet itu sendiri.Media sosial adalah konten online yang dibuat menggunakan teknologi penerbitan yang sangat mudah diakses dan terukur (Muhamad badri \& Titi Antin,2015).Philip Kotler dan Kevin Lane Keller (2016) Media sosial adalah media yang digunakan oleh konsumen untuk berbagi teks, gambar, suara, dan video informasi baik dengan orang lain maupun perusahaan dan vice versa. Menurut Varinder Taprial dan Priya Kanwar (2012) Media sosial adalah media yang digunakan oleh individu agar menjadi sosial, atau menjadi sosial secara daring dengan cara berbagi isi, berita, foto dan lain-lain dengan orang lain(Ambar,2017). Papacharissi dalam kirana (2011) mengatakanpada umumnya istilah media sosial dipakai bersama-sama dengan sejumlah istilah lainnya yang memiliki pengertian sama, seperti media baru/newmedia, media digital/digital media, situs jejaring sosial/social networking sites, online social network, dll (Muhamad Badri \& Titi Antin,2015).

Instagram merupakan salah satu aplikasi dari perkembangan teknologi informasi. Instagram adalah sebuah aplikasi berbagi foto dan video yang memungkinkan pengguna mengambil foto,mengambil video, filter digital, dan membagikanya ke berbagai layanan jejaring sosial,termasuk milik instagram sendiri (Wikipedia ensiklopedia bebas,2012). Atau bisa juga diartikan instagram adalah sarana yang digunakan oleh orang-orang untuk berinteraksi satu sama lain dengan cara mencipotakan, berbagi, serta bertukar informasi dan gagasan dalam sebuah jaringan dan komunikasi virtual (MC Graw Hill Dictionary, 2017). Kata "insta" berasal dari kata "instan", seperti kamera polaroid yang pada masanya lebih dikenal dengan sebutan "foto instan".

Instagram juga dapat menampilkan foto-foto secara instan, seperti polaroid di dalam tampilannya. Sedangkan untuk kata "gram" berasal dari kata "telegram", dimana cara kerja telegram sendiri adalah untuk mengirimkan informasi kepada orang lain dengan cepat. Sama halnya dengan Instagram yang dapat mengunggah foto dengan menggunakan jaringan internet, sehingga informasi yang ingin disampaikan dapat diterima dengan cepat. Oleh karena itulah Instagram berasal dari instan-telegram (Rangga raditya,2015).Instagram adalah jejaring social yang lahir dari sebuah perusahaan bernama Burn. Inc yang terdiri pada 8 Oktober 2010, perusahaan ini didirikan oleh Kevin Syistrom dan Mike Krieger yang saat ini menjadi CEO Instagram

Salah satu fitur yang unik di instagram adalah memotong foto menjadi bentuk persegi,sehingga terlihat seperti hasil kamera Kodak instamatic dan polaroid.Instagram hadir sebagai media sosial yang menawarkan fasilitas berbeda dengan media sosial pendahulunya.Fasilitas yang diberikan tidak hanya sekedar tentang foto dan video tetapi juga bisa memberikan pesan atau chat kepada pengguna lain.Tidak hanya itu saja penggunanya sekarang diseluruh dunia sudah melebihi 8 juta pengguna.Berdasarkan riset sensor Tower,instagram merupakan aplikasi paling populer nomor 3 pada quartal kedua tahun 2020 dengan pengguna aktif lebih dari satu miliar perbulan berdasarkan penelitian We Are Social 2020 (Arindra Meoudia,2020). Tak heran jika saat ini instagram sangat trend dikalangan remaja yang sangat sering digunakan.

Remaja merupakan waktu manusia berumur belasan tahun.Masa remaja adalah masa peralihan manusia dari anak-anak menuju dewasa.Remaja merupakan masa transisi dari anak anak hingga dewasa,fase remaja mencerminkan cara berpikir remaja masih dalam koridor berpikir konkret.Fase remaja atau masa peralihan dari anak menjadi dewasa yaitu (10-20) tahun.Remaja menurut WHO dalam Sarwono (2011: 12) membagi kurun usia menjadi 2 bagian yaitu remaja awal 10-14 tahun dan remaja akhir 15-20 tahun (Tiara Devi Farisa ,Sri Maryati Deliana, Rulita Hendriyani,2013).Pada masa ini mereka sedang mencari hal hal yang baru dan apa yang disukai. Pada fase ini pula kecenderungan meniru terjadi baiksecara sadar maupun tidak sadar.Tidak hanya itu,terlebih lagi remaja sangat cepat beradaptasi dengan teknologi modern seperti media sosial.

Kehadiran media sosial seakan tidak dapat dilepaskan dari kehidupan remaja karena pada saat ini hampir setiap hari,jam,menit bahkan detik tidak berhenti untuk update status (Bimo Mahendra,2017), bahkan pada saat makan,berjalan,dan belajar.Selain itu,lingkungan terdekat seperti keluarga,teman, dan lingkungan mereka yang sama-sama menggunakan media sosial 
seperti instagram, dapat memicu mereka menggunakan aplikasi tersebut.Membicarakan masalah remaja rasanya tak akan lepas dari beberapa aspek pada mereka yang rata-rata masih berusia belasan tahun.Mulai dari kondisi mereka yang masih labil serta keinginan untuk tampil eksis dan ingin diakui oleh lingkunganya.

Dengan usia mereka yang masih belia lebih suka ketika memiliki sebuah hal yang dapat membanggakan.Remaja saat ini sedang berjuang untuk menemukan jati dirinya sendiri. Selain itu, dengan adanya media sosial memudahkan mereka untuk berinteraksi dan bergaul.Salah satunya media sosial instagram yang bisa berinteraksi dengan orang lain menggunakan internet.Menurut O'Brien (2021) internet adalah suatu jaringan komputer yang berkembang sangat pesat serta memberikan manfaat untuk berbagai macam kepentingan, mulai dari pendidikan, bisnis, hingga jaringan pemerintahan yang saling berhubungan antara satu dengan yang lainnya. Selama ada internet remaja saat ini bisa saja menggunakan media sosial instagram secara terus menerus tanpa henti karena mereka giat ingin eksis. Tidak hanya itu instagram tidak ada pusat dan tombol untuk mematikan dan menyalakan internet sehingga internet sangat sulit dikendalikan oleh orang yang ingin melakukanya.

Kemunculan situs instagram yang memudahkan penggunanya untuk berteman dengan siapa saja, sangat digemari dikalangan remaja.Remaja seringkali meminta pendapat persetujuan rekan-rekanya untuk memutuskan sesuatu dalam instagram.Remaja mampu berpikir kritis dalam memilih mana yang benar dan mana yang salah.Dalam cakupan yang luas instagram memberikan wawasan bagi remaja tentang informasi yang diberikan baik berupa foto atau video bagi mereka. Selain itu, disisi lain juga jika dipergunakan secara tidak benar maka bisa saja itu akan membuat dirinya menimbulkan hal yang buruk bagi mereka.Dalam pertemanan, remaja bisa memilih-milih mana yang baik untuk dijadikan teman mana yang buruk. Tidak hanya itu, aktivitas yang kita bagikan melalui foto dan video akan dilihat oleh orang yang dijadikan teman oleh mereka.

Penggunaan media sosial instagram dari tahun ke tahun semakin meningkat.Berdasarkan data, remaja saat ini usia 14-21 banyak sekali menggunakan instagram terlebih lagi mereka gunakan untuk kesenangan dan membagikan aktivitas yang mereka lakukan tanpa pengawasan yang bisa saja hal itu memicu sesuatu yang negatif.Orang tua perlu memposisikan diri sebagai pengawas anak dengan beberapa cara yaitu penerapan aturan penggunaan yang ketat,berteman dengan anaknya di media sosial, pembatasan kuota, pendekatan personal dan menggunakan unsur ketuhanan (Mutia rahma pratiwi,Mukaromah,Wulan Herdiningsih,2018). Hal seperti ini dilakukan supaya mereka dalam menggunakan media sosial ini tidak salah arah. Dalam hal ini,instagram memberlakukan batas minimal 16 tahun. Data yang diperoleh masih banyak remaja 16 tahun kebawah yang menggunakan instagram.Secara psikologis umur yang belum begitu cukup untuk menggunakan instagram bisa berdampak pada psikologis mereka apabila terjadi hal yang buruk. Biasanya para remaja akan menggunakan media yang memiliki fasilitas lebih seperti instagram mereka akan menggunakanya sesuka mereka dan tidak tau dampak yang terjadi setelah melakukan itu.Oleh karena itu perlu diketahui apa saja yang dapat disebabkan jika instagram digunakan secara berlebihan.

\section{METODE PENELITIAN}

Penelitian ini menggunakan metode kualitatif, secara rinci kualitatif memberikan ruang kepada peneliti untuk mengeksplorasi secara deskriftif tentang fenomena yang diteliti, sehingga diperoleh sebuah kebijakan untuk melakukan tindakan atau sikap.Fokus dalam penelitian ini adalah mengetahui penggunaan media sosial instagram secara berlebihan di kalangan anak remaja. Jenis dan sumber data dalam penelitian ini dikumpulkan berdasarkan pengelompokan data primer dan sekunder. Data primer diperoleh melalui wawancara terhadap anak remaja usia16-24 tahun maupun melalui pengamatan lapangan. Data sekunder adalah data yang diperoleh dari jurnal-jurnal dan dokumen- dokumen yang sudah tercatat. Teknik pengumpulan data yang dipakai dalam penelitian ini adalah teknik triangulasi.Karena penelitian ini menggunakan metode kualitatif, teknik pengumpulan data yang digunakan adalah observasi, wawancara, dan dokumentasi.Wawancara dilakukan secara online melibatkan beberapa pengguna instagram, pemilihan informan menggunakan purposive dengan memperhatikan kriteria. 


\section{HASIL DAN PEMBAHASAN}

Penelitian ini dilakukan untuk melihat bagaimana identifikasi pengaruh penggunaan media sosial dikalangan anak remaja.Tidak bisa dipungkiri bahwa media sosial mempunyai pengaruh yang besar dalam kehidupan seseorang.Berdasarkan pendapat narasumber yang kami wawancarai bahwa ada beberapa hal yang menjadi pengaruh positif penggunaan instagram pada beliau dalam penggunaanya, salah satunya ia menjadi lebih mudah mencari barang yang sedang dicari atau dibutuhkan. Hal ini sesuai dengan teori Waralah Cristo yang mengemukakan bahwa sesuatu yang diakibatkan oleh sesuatu yang diinginkan, bisa positif atau negatif atau pengaruh kuat yang mendatangkan akibat baik negatif maupun positif.

Selain pengaruh positif yang disebabkan oleh instagram, ada juga pengaruh negative. Sebagian orang gaya hidup bisa dinilai dengan hanya melihat dinding dalam sosial medianya saja termasuk melihat akun instagram seseorang, jadi banyak dari sebagian orang merasa kurang percaya diri atau terlihat insecure dalam hal ini.Berdasarkan pendapat seorang remaja wanita mengatakan jika ia tidak percaya diri karena fisik gemuk dan wajah kurang cantik dibandingkan foto yang diunggah oleh orang lain.Selain itu ,kita juga tidak bisa membenarkan melihat gaya hidup hanya dari postingan saja karena foto atau video selama 1 menit tidak bisa menggambarkan kepribadian seseorang. Hal ini terhubung dengan teori yang dikemukakan oleh (Chang, Jerry dan Khong, 2014) kemungkinan jika pelajar terpapar terhadap tekanan untuk berpenampilan lebih baik ketika mengakses media sosial seperti instagram sehingga muncul sikap orientasi penampilan. Individu menakuti bahwa penampilan dievaluasi secara negatif oleh orang lain sehingga mereka mulai membentuk perilaku yang mencerminkan orientasi terhadap penampilan.

Dilansir dari laman New York Post.Peneliti utama yakni Martin graff mengungkapkan jika orang-orang yang senang bermain sosial media instagram khususnya wanita,akan merasa jika tubuh kurus adalah kriteria tubuh cantik. Wanita yang kerap melihat postingan orang lain yang lebih cantik,menawan,dan cerdas akan cenderung menyesal dengan kondisi dirinya sendiri dan tida puas dengan apa dimilikinya.Martin Graff mengatakan menghabiskan banyak waktu untuk bermain media sosial dan membandingkan dirinya dengan orang lain,ini akan membuat rasa percaya diri berkurang.Orang-orang juga cenderung hanya akan memposting apa-apa yang membuatnya keren dan tidak percaya dengan dirinya sendiri yang apa adanya.

Di kalangan remaja media sosial instagram sangat berpengaruh terhadap kesehatan mental, karena terkadang instagram bisa menjadi penenang dan menaikan mood dan bisa juga membuat stress apabila melihat unggahan atau tulisan yang membuata takut atau marah. Hal ini sesuai dengan teori yang dikemukakan oleh Kurt Lewin (1951, dalam Brigham, 1991) perilaku adalah fungsi karakteristik individu dan lingkungan, karakteristik inilah yang meliputi berbagai variable seperti nilai nilai, motif, sifat kepribadian, dan sikap yang saling berinteraksi pula dalam faktor- faktor lingkungan dalam menentukan perilaku.

Dilansir dari Tirto.id Unggahan Foto-foto liburan dan kehidupan pribadi dengan caption atau tulisan seseorang remaja di instagram bisa memicu rasa iri dan perilaku membanding-bandingkan dalam diri pengguna.Ujung nya rasa putus asa karena menilai hidup sendiri tak semenyenangkan hidup orang-orang yang diamati di Instagram.Kecemasan akan ketinggalan tren atau isu-isu yang marak diperbincangkan akan membuat seorang remaja stress. Jika tidak bijak dalam menggunakan instagram, selain berpengaruh terhadap kesehatan mental, instagram juga berpontensi mengancam keselamatan penggunanya, seperti perilaku bullying yang mengancam kesehatan fisik maupun mental.Hal tersebut sesuai dengan teori yang disampaikan oleh (Carpenter 2016, Daini et. al, 2013, Leuis at.Al, 2015) yang menjelaskan tentang selfharm kecenderungan mencari perhatian dari publik ini didorong oleh perasaan kesepian dan mencari sensasi dan perhatian (mengikuti temannya) yang utamanya terjadi di kalangan remaja.

Dilansir dari merdeka.com penyebab bullying pada anak remaja dalam instagram yaitu datang dari faktor keluarga. Anak yang tumbuh dan berkembang dalam keluarga yang harmonis, orang tua yang terlalu emosional dan tidak memperhatikan orang tua terhadap anaknya dapat menyebabkan timbulnya perilaku menyimpang pada perilaku bullying dalam seorang remaja.Orang tua yang terlalu sibuk dan kurang perhatian pada anak dapat menyebabkan pemikiran tidak sempurna pada anak. Anak remaja yang mengalami sosialisasi tidak sempurna ini kemungkinan memiliki perilaku menyimpang. Anak remaja bisa menjadi pelaku bullying di antaranya karena kemampuan adaptasi yang buruk, pemenuhan eksistensi diri yang kurang, harga diri yang rendah, 
pemenuhan kebutuhan yang tidak terpuaskan di aspek lain dalam kehidupan. Bahkan pelaku ini juga bisa merupakan korban bullying sebelumnya sehingga melampiaskanya dala media sisial Instagram.Dilansir dari kompas.com sebanyak $60 \%$ remaja mengaku pernah mengalami tindakan bullying dan $87 \%$ lainnya pernah mengalami perundungan secara online. Terlebih dalam kondisi pandemi Covid-19 saat ini, sebagian besar aktivitas telah beralih secara daring (online).

Namun apabila kita bijak dalam penggunaanya, media sosial instagram mampu dijadikan sebagai wadah untuk menyalurkan hobi seperti hobi menulis indah (kaligrafi, lettteting) yang akhirnya dapat menghasilkan uang apabila karyanya di jual. Atau hobi bernyanyi, menggambar, membuat video animasi, video memasak dan video kreatif lainnya, atau mengunggah foto hasil jepretan kamera bagi yang menyukai fotografi dan masih banyak lagi unggahan hobi yang sering kita temukan di instagram. Pernyataan ini berhubungan dengan teori Mikik (Miller et. Al 2016) yang menyebutkan bahwa media sosial tidak hanya media yang memiliki fungsi untuk berkomunikasi dan bersosialisasi. Media sosial juga berguna sebagai media yang dapat digunakan untuk menyalurkan hobi, sebagai sarana hiburan seperti bermain game atau sekedar melihat foto dan video. Selain itu media sosial juga sebagai tempat media komersil berlangsung seperti melakukan promosi untuk menjual produk tertentu.

\section{KESIMPULAN}

Saat ini teknologi internet dan mobile phone semakin maju maka media sosial pun ikut tumbuh dengan pesat.Kaum remaja saat ini amat sangat ketergantungan terhadap media sosial. Mereka begitu identik dengan smartphone yang hampir 24 jam berada di tangan dan sangat sibuk berselancar di dunia online yang seakan tidak pernah berhenti. Apalagi kini untuk mengakses instagram misalnya, bisa dilakukan dimana saja dan kapan saja hanya dengan menggunakan sebuah mobile phone.berita. Melihat hal ini, kami melakukan riset mengenai penggunaan media sosial khususnya instagram di kalangan remaja. Hasilnya menunjukkan, banyak sisi positif maupun negative bagi anak remaja.ccontohnya, Kalangan remaja yang menjadi hiperaktif di media sosial ini juga sering memposting kegiatan sehari-hari mereka yang seakan menggambarkan gaya hidup mereka yang mencoba mengikuti perkembangan jaman, sehingga mereka dianggap lebih populer di lingkungannya. Namun apa yang mereka posting di media sosial tidak selalu menggambarkan keadaan social life mereka yang sebenarnya. Ketika para remaja tersebut memposting sisi hidup nya yang penuh kesenangan, tidak jarang kenyataannya dalam hidupnya mereka merasa kesepian.Manusia sebagai aktor yang kreatif mampu menciptakan berbagai hal, salah satunya adalah ruang interaksi dunia maya. Seharusnya ada peran dari sekolah atau orang sekitar dalam menangani masalah yang terjadi pada kalangan remaja agar dapat menggunkan media sosial dengan bijak. Namun apabila menggunakannya dengan bijak, instagram dapat dijadikan wadah untuk menyalurkan hobi bahkan untuk mendapatkan pengasilan tambahan dari endorse. Dan ini bagus untuk kalangan remaja untuk menambah uang jajan dan menjadi mandiri.

\section{Referensi}

Agianto, R., Setiawati, A., \& Firmansyah, R. (2020). "Pengaruh Media Sosial Instagram Terhadap Gaya Hidup dan Etika Remaja". TEMATIK- Jurnal Teknologi Informasi dan Komunikasi, 7(2),130-139.

Bimo Mahendra (2017),Eksistensi sosial remaja dalam instagram (sebutan perspektif komunikasi).Jurnal Visi Komunikasi Vol.16 No.1.Hal 157.

Dr. Rizal Fadli Halodoc (2020). Pengaruh Media Sosial Pada Kesehatan Mental Remaja. Diakses pada tanggal 08 Juli 2021, dari https://www.halodoc.com/artikel/pengaruh-media-sosial-pada-kesehatan-mentalremaja

Fimela (2018).Bermain media sosial menurunkan rasa percaya diri pada wanita.Diakses pada tanggal 10 Juli 2021 dari https://www.fimela.com/beauty-health/read/3814576/bermain-media-sosial-menurunkanrasa-percaya-diri-pada-wanita

Kevin Rizky Pratama (2021).Instagram media sosial pemicu "cyberbullying" tertinggi.Diakses pada tanggal 10 Juli 2021 dari, https://tekno.kompas.com/read/2021/03/29/07164137/instagram-media-sosial-pemicucyberbullying-tertinggi

Muhamad Badri \& Titi Antin (2015),Adopsi inovasi media sosial mahasiswa jurusan IImu Komunikasi FDK UIN SUSKA BANDUNG RIAU.Jurnal risalah Vol.26 No.4, Hal 183 \& 186.

Mutia Rahmi Pratiwi,Mukaromah,Wulan Herdiningsih (2018).Peran Pengawasan orang tua pada anak pengguna media sosial ,The Supervision role of parents for social media chikdren users.Jurnal penelitian pers dan komunikasi pembangunanVol.22 No.1. Hal 37. 
Novi Puji Astuti (2020).Peyebab bullying pada anak,cegah sedini mungkin.Diakses pada tanggal 10 Juli 2021, dari https://www.merdeka.com/jabar/penyebab-bullying-pada-anak-cegah-sedini-mungkinkln.html?page $=2$

Patresia Kinandita (2017).Baik buruk efek instagram bagi kesehatan mental.Diakses pada tanggal 10 Juli 2021,dari https://amp.tirto.id/baik-buruk-efek-instagram-bagi-kesehatan-mental-csr7

Rangga Aditya (2015), Pengaruh Media Sosial Instagram Terhadap Minat Fotografi Pada Komunitas Fotografi Pekanbaru..Jurnal online mahasiswa FISIP Vol.2 No.2.Hal 3.

Tiara Devi Farisa ,Sri Maryati Deliana, Rulita Hendriyani (2013),Faktor - faktor penyebab perilaku seksual menyimpang pada remaja Tunagrahita SLB N SEMARANG.Jurnal online Develovement and clynical psychology Vol.2 No.1. Hal 28.

Triastuti, Endah. (2017). Dampak Penggunaan Media Sosial Bagi Anak dan Remaja. Diakses pada tanggal 08 Juli 2021, dari, http://eksis.ditpsmk.net/uploads/book/file/73EFA4C1-D6AD-416E-82507641260FD55B/seribukuliterasidigital-kajiandampakmediasosialbagianakdanre.pdf 